\title{
Human Development Convergence and the Impact of Funds Transfer to Regions: A Dynamic Panel Data Approach*
}

\author{
Rah Adi Fahmi GINANJAR ${ }^{1}$, Vadilla Mutia ZAHARA², Stannia Cahaya SUCI ${ }^{3}$, Indra SUHENDRA ${ }^{4}$
}

Received: September 01, 2020 Revised: October 26, 2020 Accepted: November 05, 2020

\begin{abstract}
This study analyzes human development convergence and the impact of funds transfer to the regions using $\sigma$ and $\beta$-convergence analysis method. Observations were made in all Indonesia's provinces in the period 2010-2019. The coefficient of variation calculation shows a dispersion in the inequality of human development, which means that convergence occurred. This is also documented by the clustering analysis results developed in the study. The results are in line with the hypothesis of neoclassical theory, which shows the tendency for provinces with lower human development levels to grow relatively faster. The dynamic panel data approach with the GMM model shows that a model built with explanatory variables for transfer of funds to regions may lead to the process of convergence of human development $-2.21 \%$ per year or 31 years to cover the half-life of convergence. This is a consequence of the Special Allocation Fund and the Village Fund, which positively impact the convergence process, and the General Allocation Fund and the Revenue Sharing Fund with negative signs slowing the convergence process. This evidence opens opportunities to review the justification of the weighting component in determining the amount of funds transferred to the region to accelerate the convergence process of human development.
\end{abstract}

Keywords: Human Development, Convergence, Inequality, Fiscal Decentralization, GMM

JEL Classification Code: O15, O47, E60, H72, R19

\section{Introduction}

The development should be evaluated to determine the extent of success and what is needed to improve community

\section{*Acknowledgements:}

[1] The authors would like to acknowledge financial support from Universitas Sultan Ageng Tirtayasa for this research (Grant Number: 351/UN43/KPT.PT.01.02/2020).

[2] We also thank Sicesa Scientia for proofreading our manuscript.

${ }^{1}$ First Author and Corresponding Author. Assistant Professor, Department of Economics and Development Studies, Universitas Sultan Ageng Tirtayasa, Indonesia [Postal Address: Jalan Raya Jakarta Km. 4, Serang City, Banten, 42118, Indonesia]

Email: rah.adi@untirta.ac.id

${ }^{2}$ Assistant Professor, Department of Economics and Development Studies, Universitas Sultan Ageng Tirtayasa, Indonesia.

Email: vadillamutia@untirta.ac.id

${ }^{3}$ Assistant Professor, Department of Economics and Development Studies, Universitas Sultan Ageng Tirtayasa, Indonesia.

Email: stanniacs@untirta.ac.id

${ }^{4}$ Assistant Professor, Department of Economics and Development

Studies, Universitas Sultan Ageng Tirtayasa, Indonesia.

Email: indras_23@untirta.ac.id

(c) Copyright: The Author(s)

This is an Open Access article distributed under the terms of the Creative Commons Attribution Non-Commercial License (https://creativecommons.org/licenses/by-nc/4.0/) which permits unrestricted non-commercial use, distribution, and reproduction in any medium, provided the original work is properly cited. welfare. Conventionally, welfare evaluation relies on percapita gross value-added as an indicator for measuring life standards. There are alternative indicators often used to measure an area's development achievements, including the human development index (HDI). As a development measure, HDI is more comprehensive than other indicators because it describes human development from several aspects, including education, health, and the economy. For this reason, it is perceived to be a foundation for increasing welfare. Marchante and Ortega (2006) revisited the regional welfare problem using alternative composite indicators of the United Nations Development Program (UNDP) through HDI. Area development is essentially human and needs to be prioritized.

In Indonesia, human development between regions is reflected in the diversity of HDI between provinces, as shown in Figure 1. The average HDI of each province has been divided in different levels over the past decade, including low, medium, and high. In 2019, Jakarta Province achieved a very high HDI level of 80.76 . This has several implications, such as the inequality in human development, and failure to maximize development. The inequality shows that the national HDI value does not represent the entire Indonesian territory. 


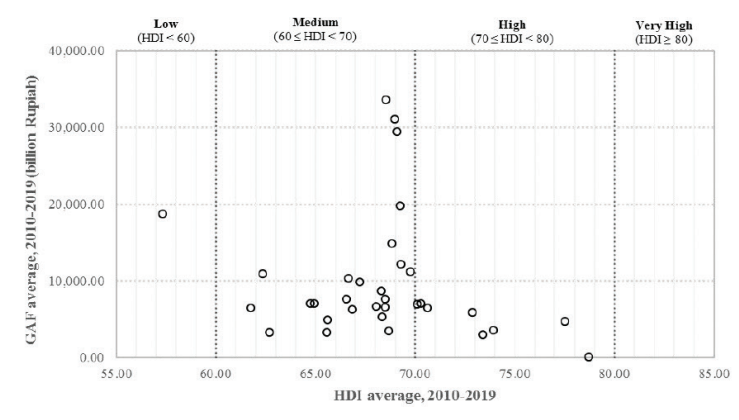

Figure 1: The interaction of the Human Development Index (HDI) and General Allocation Fund (DAU) of all provinces in Indonesia, 2010-2019

Since the enactment of Government Regulation of Indonesia Number 55 of 2005, HDI has been critical in determining funds transfer to regions (balancing funds), particularly the General Allocation Fund (Dana Alokasi Umum, DAU). The objective of DAU is to equalize the distribution of financial capacity between regions to fund regional needs via decentralization. The funds are allocated based on a formula consisting of a fiscal gap and basic allocation. The fiscal gap is the difference between fiscal needs and capacity, measured using the HDI and several other variables. Therefore, HDI is a critical determinant for DAU. Figure 1 shows that provinces with a lower HDI do not necessarily receive a higher DAU. This indicates that HDI is not prioritized in measuring regional needs to determine the amount of DAU. With a larger DAU, regions with lower levels of human development receive additional funding for their development. These areas are expected to catch up with the development of regions with higher levels of human development to reduce inequality or converging. Inequality raises various questions, including whether there is a convergence of human development in Indonesia. Another critical aspect is whether DAU or other funds transfer to the regions contribute to the convergence process of human development.

Over the last two decades, studies show the development convergence process from economic variables such as gross domestic product (GDP), income, and growth. These studies include Yaya et al. (2020), Abosedra et al. (2019), Wang (2020), Liu (2019), Fufa and Kim (2018), Cosci and Mirra (2018), Li et al. (2016), Yusuf et al. (2014), Andreano et al. (2013), Xueliang (2013), Magrini et al. (2015), BouayadAgha and Lionel (2010), Firdaus and Yusop (2009), Dobson and Ramlogan (2002), Choi and Li (2000), and Raiser (1998). Static and dynamic analyses are widely used to test hypotheses of related studies. Therefore, research related to convergence is generally divided into two approaches $\sigma$-convergence, which includes static analysis by calculating various variation coefficients, and $\beta$-convergence, which includes dynamic analysis dominated by the generalized method of moments (GMM).

Studies on the convergence of human development are rarely conducted, particularly aspects linking convergence to regional financial policy instruments, such as funds transfer to regions. Studies analyzing the convergence of human development have been conducted using various approaches. However, studies linking the convergence of human development with funds transfer to regions are still limited in Indonesia. Castro and Martins (2018) analyzed the impact of elections, partisan support, and the effects of political support on human development dynamics. The study used panel data from 82 countries over the 1980-2013 period with the GMM model. Vidyattama (2013) examined regional convergence in Indonesia represented by the percapita GRDP indicator and HDI using the $\sigma$-convergence approach with Williamson Index and $\beta$-convergence, with the spatial auto-regressive lag model (SAR), and the spatial autoregressive error model (SEM). Mayer-Foulkes (2012) examined the interaction of HDI components between countries, including income, life expectancy, literacy rate, and the ratio of long schooling to the average length of the school. The study used descriptive statistical analysis approaches and static panel data regression models. Noorbakhsh (2007) examined the concept of convergence extended to the HDI variable with observations between countries. The $\sigma$-convergence approach is used with various measurements of variation coefficient and $\beta$-convergence with static panel data.

To fill gaps in the literature on the convergence of human development associated with funds transfer to regions and to explain previous findings, this study aims to 1) analyze the convergence of human development between regions in Indonesia, and 2) determine the impact of funds transfer to the regions on the convergence of human development. The results are expected to criticize the current policy on transferring funds to regions for accelerating the convergence process of human development in Indonesia. 


\section{Literature Review}

The decrease in disparity or inequality between regions over a certain period can be reflected in the convergence condition. There are two main approaches to regional convergence research. First, classic references related to regional development disparities have been made by Williamson (1965). The study described the regional convergence process related to national development. It stated that regional income disparities converge after three phases, from the initial development to the maturity stage. This regional inequality is analyzed independently from the growth theory. Second, the convergence research was carried out by Barro and Sala-i-Martin (1991, 1995) using a cross-section regression approach between the growth rate and the initial per-capita income. The study examined the two approaches to identify the advantages and weaknesses of each of them.

Some studies analyzed the interaction among regional financial policy instrument variables associated with human development, but not the convergence process. For instance, research conducted by Wulandari et al. (2018) analyzed the effect of local government original Income, general allocation funds, special allocation funds, stock funds, other legal income, and budget surplus/deficit on the human development index through capital expenditure in Indonesia using path analysis. Mutiha (2018) examined the effect of local own revenue, tax sharing, general allocation funds, and special allocation funds for the HDI, a benchmark for assessing the performance of the provincial government using multiple regression. Other studies analyzed human development with different variables. For instance, Dash and Mukherjee (2015) examined political competition, which may have a similar effect on economic performance by linking political competition with the HDI of the Indian states. Nayyar (2012) conducted a qualitative analysis of the interactions between macroeconomics in terms of objectives and policies and human development, primarily people's well-being. Ocampo and Vallejo (2012) analyzed the process of human development with precarious employment and economic insecurity. Habibi et al. (2003) contributed to the empirical relationship between fiscal decentralization and human development by documenting the positive impact of devolutionary decentralization on health and education indicators.

Analyses have been made of the convergence of various other variables as observations have also been developed, including the fiscal convergence by Khan et al. (2020), the convergence of transportation system by Liu (2019), the convergence of renewable energy by Berk et al. (2018), total factor productivity convergence by Männasoo et al. (2018), the convergence of performance in the development of hightech industries by Ze-Lei et al. (2017), human capital by Sab and Smith (2016), public expenditure by Apergis (2015), and income distribution by Bao and Dhongde (2009). These convergence studies have used the GMM model to answer their respective research questions

\section{Research Methods and Materials}

\subsection{Estimation Procedure and Econometric Strategy}

The research begins by analyzing the dispersion of regional human development inequality, where convergence occurs. The dispersion is generally measured by the standard deviation (SD) of the human development index (HDI) between regions, decreasing over time. This process is called $\sigma$-convergence (Barro \& Sala-i-Martin, 1992). It features a weighted coefficient of variation as a modification of the Williamson Index to measure inter-regional inequality over time, as shown below:

$$
C V w=\frac{\sqrt{\sum_{i=1}^{n}\left(Y_{i}-\bar{Y}\right)^{2} \frac{P_{i}}{P}}}{\bar{Y}}
$$

Where: $C V_{w}=$ weighted coefficient of variation ; $n=$ number of provinces; $Y_{i}=$ human development index (HDI) of province i; $\bar{Y}=$ average of HDI; $P_{i}=$ population of province $\mathrm{i}$; and $P=$ total population. Although calculations from standard deviation and weighted coefficient of variation are used to analyze changes in regional inequality, convergence cannot indicate which regions are growing relatively faster or slower. Therefore, to investigate these conditions, a clustering analysis was developed for each province with the clustering classification in Table 1.

Where: $\overline{H D I}_{i}=$ average HDI of province $\mathrm{i}$ during the observation period, 2010-2019; $\bar{g}_{i}=$ average HDI growth of province $i$ during the observation period, 2010-2019; $\bar{G}_{i}=$ average of $\bar{g}_{i}$. Based on neoclassical theory, the convergence criteria occur in case regions with lower HDI levels have relatively faster growth rates and vice versa. In general, regions with higher HDI levels have relatively slow growth rates. Convergence occurs when pattern dominance is in clusters I and IV, otherwise, the pattern diverges.

Table 1: Classification of Clustering Analysis

\begin{tabular}{|c|c|}
\hline $\begin{array}{l}\text { Cluster I } \\
\text { low/middle level } \\
\left(\overline{H D I}_{i}<70\right) \\
\text { and rapidly growing } \\
\left(\bar{g}_{i}>\bar{G}\right)\end{array}$ & $\begin{array}{l}\text { Cluster II } \\
\text { high/very high level } \\
(\overline{H D I} \geq 70) \\
\text { and rapidly growing } \\
\left(\bar{g}_{i}<\bar{G}\right)\end{array}$ \\
\hline $\begin{array}{l}\text { Cluster III } \\
\text { low/middle level } \\
\left(\overline{H D I}_{i}<70\right) \\
\text { and slowly growing } \\
\left(\bar{g}_{i}<\bar{G}\right)\end{array}$ & $\begin{array}{l}\text { Cluster IV } \\
\text { high/very high }\left(\overline{H D I}_{i} \geq 70\right) \\
\text { and slowly growing }\left(\bar{g}_{i}<\bar{G}\right)\end{array}$ \\
\hline
\end{tabular}


Furthermore, convergence speed analysis is introduced in growth analysis, specifically $\beta$-convergence. It can be used to test whether areas with relatively low human development levels are growing significantly faster than regions with high levels of human development, an indication of declining inequality. One of the main advantages of $\beta$-convergence is its dynamic analysis. In case short-term observations cannot explain the impact of public policy, it can be reflected in a long-term tendency.

In empirical studies on $\beta$-convergence analysis, the convergence hypothesis's test involves examining the behavior and characteristics of the region. Therefore, the $\beta$-convergence conditional is applied to the analysis with a hypothesis containing characteristic differences in technology, preferences, and institutions between regions. The characteristic homogeneity hypothesis shows that human development growth is only influenced by the level of initial human development index, and supports the application of absolute $\beta$-convergence (Barro \& Sala-iMartin, 1992). Therefore, this study uses both approaches to test each hypothesis.

The convergence model estimation is conducted using a dynamic panel data analysis method or the Generalized Method of Moments (GMM) model. This is due to the lag of the dependent variable, HDI, as the model specification's independent variable. The dynamic relationship results in the emergence of endogeneity problems when the model is estimated using static panel data analysis produces biased and inconsistent estimators (Verbeek, 2004).

Dynamic panel data analysis is driven by the growing, dynamic relationships between economic variables in relation to the dynamic adjustment analysis. This dynamic relationship is characterized by the presence of a lag-dependent variable as an independent variable resulting in the emergence of endogeneity problems. In case the model is estimated with a static panel data analysis, biased and inconsistent predictors that can be overcome by the GMM model. In this study, the model was estimated using the dynamic panel data method with the GMM model following Arellano and Bond (1991) and the first differences (FD-GMM) model. Since the GMM estimator in the first differences has been criticized in the literature, it is more appropriate to use the system (Sys-GMM) model, as suggested by Blundell and Bond (1998). In this case, a system of equations is estimated in first differences and levels. Therefore, the dynamic panel data model evaluation determines the right model to be unbiased, consistent, and valid.

The empirical test of the convergence prediction of neoclassical growth theory is conducted based on diminishing returns to capital. This study uses a regression model from Barro and Sala-i-Martin (1992). The model uses an equation related to the growth rate of the human development index between two points in time to the initial level of the human development index. To test the absolute and conditional $\beta$-convergence hypothesis, the following model is used:

$$
Y_{i, t}=\frac{1}{T} \ln \left(\frac{Y_{i, t}}{Y_{i, t-1}}\right)=\frac{1}{T}\left[\left(\ln \left(Y_{i, t}\right)-\ln \left(Y_{i, t-1}\right)\right]\right.
$$

$Y_{i, t}$ in equation 2 is then used as the dependent variable in equation 3 as follows:

$$
\begin{aligned}
& Y_{i, t}=\alpha-\beta \ln Y_{i, t-1}+\gamma X_{i, t-1}+u_{i, t-1} \\
& -\beta=\left(1-e^{-\lambda}\right) \text { or } e^{-\lambda}=1+\beta
\end{aligned}
$$

Where: $Y=$ growth variable; $X=$ steady-state qualifiers variable; $T=$ number of observation time periods; $t=$ year; $i=$ province; $e=$ natural logarithmic number; $u=$ error term.

This study used 1 observation period. Therefore 1/T in equation 2 above has been eliminated, and the model specification for the absolute $\beta$-convergence approach is written in equation 5 as follows:

$$
\ln \left(H D I_{i, t}\right)-\ln \left(H D I_{i, t-1}\right)=\beta_{0}+\beta_{1} \ln \left(H D I_{i, t-1}\right)+u_{i, t}
$$

To determine the impacts of balancing funds and village funds on human development, the conditional $\beta$-convergence model is used. This is an absolute $\beta$-convergence model coupled with an explanatory variable describing the characteristics of each province. In this case, variables from regional financial policy instruments are used, including balancing and village funds. The test for conditional $\beta$-convergence hypothesis uses the model specifications in equation 6 as follows:

$$
\begin{array}{r}
\operatorname{Ln}\left(H D I_{i, t}\right)-\ln \left(H D I_{i, t-1}\right)=\beta_{0}+\beta_{1} \ln \left(H D I_{i, t-1}\right)+\beta_{2} \ln \\
\left(R S F_{i, t}\right)+\beta_{3} \ln \left(G A F_{i, t}\right)+\beta_{4} \ln \left(S A F_{i, t}\right) \beta_{5} \ln \left(V F_{i, t}\right)+u_{i, t}
\end{array}
$$

Where: $H D I=$ human development index; $R S F=$ revenue sharing fund; $G A F=$ general allocation fund; $S A F=$ special allocation fund; $V F=$ village fund; $t=$ year; $i=$ province; $u$ $=$ error term.

The convergence process occurs when the coefficient of $\beta 1$ is less than 1 , with convergence speed expressed as $\lambda$. Based on Barro \& Sala-i-Martin (1992) in equation 7, convergence speed measures how fast the economy reaches a steady state. The half-life test in equation 8 shows the time needed to reach a steady-state from the inflation convergence process. It can also be the time required to achieve half of the convergence of human development expressed by $\tau$.

$$
\begin{gathered}
\lambda=-\frac{\ln \left(\beta_{1}\right)}{T} \\
\tau=\frac{-\ln (0.5)}{-\ln \left(\beta_{1}\right) / T}=\frac{\ln (2)}{\lambda}
\end{gathered}
$$


Where: $\lambda=$ speed convergence of human development index; $\beta_{1}=$ lag coefficient of human development index; $T=$ time periode observation; $\tau=$ half-life of convergence.

\subsection{Data}

This study uses annual panel data from 2010 to 2019 for all provinces in Indonesia, except North Kalimantan, which has limited data. Post-2010 data is used because it is the initial period of a new method for HDI counting, representing human development variables. It is sourced from the Central Statistics Agency (Badan Pusat Statistik, BPS).

The HDI methodology has evolved. The average arithmetic formula used previously shows that low performance can be covered by the high performance of another dimension, hence converted into a geometric average. Furthermore, several indicators were considered inappropriate for use in HDI calculations, such as literacy rates. It is no longer relevant in measuring education as a whole since it cannot describe the quality of education. In most areas, it is already high, and cannot distinguish the level of education between regions accurately. Therefore, it is replaced with the expected number of schooling years. The GDP per capita is unable to reflect people's income in an area, hence it is replaced by gross national product (GNI) per capita. The modern method of calculating the HDI bases on the average geometric normalized indices, reflecting the achievements in each dimension (Chulanova et al., 2019).

Data is used to represent the balancing funds variable sourced from the Indonesian Ministry of Finance (Kementerian Keuangan of Indonesia), such as revenue sharing (Dana Bagi Hasil, DBH), general allocation funds (Dana Alokasi Umum, DAU), and special allocation funds (Dana Alokasi Khusus, DAK). Since the village fund is a dummy variable, the 20102014 period is given a value of 0 because the village fund allocation has not been implemented. The 2015-2019 period is given a value of 1 , except for Jakarta Province, which is assigned 0 because there is no village fund allocation in its area. The balancing fund data represents the total funds from all local governments in a province, including provincial, district, and city governments.

\section{Results and Discussion}

\subsection{Sigma-Convergence Analysis ( $\sigma$-Convergence)}

The dispersion in the inequality of human development between provinces in Indonesia has decreased during 20102019, as shown in Figure 2. However, it is insignificant because the decline rate is relatively small, where the weighted coefficient of variation $(\mathrm{CVw})$ only drops from 0.783 in 2010 to 0.771 in 2019 , and the standard deviation (SD) only fell from 0.067 in 2010 to 0.056 in 2019 . This is indicated by its growth, where both indicators show the inequality dispersion of human development in Indonesia during the 2010-2019 period has slowly decreased with an average decline of $-0.696 \%$ per year for the $\mathrm{CVw}$ and $-0.720 \%$ per year for SD. This is in line with Vidyatama (2013) regarding regional convergence in Indonesia. It is determined based on the decrease in HDI inequality during 2005-2008, which continues to slow down until the last period of observation. Therefore, the convergence process in the study findings is relatively slow. An unusual intervention is required to accelerate the process by looking at instruments contributing to the convergence process in the $\beta$-convergence analysis.

The acceleration of the decline is faster based on accelerated growth reduction of numbers on the SD indicator in 2016-2019. This is because there was a government change in 2015, which affected acceleration, but not visible on the $\mathrm{CVw}$ indicator. Therefore, it might still be debated and proven on other occasions.

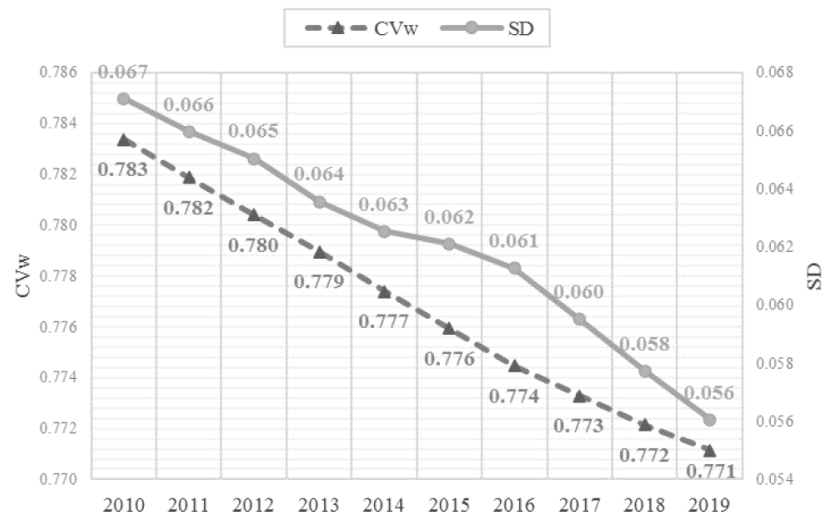

Figure 2: The Inequality Dispersion of Human Development Index (HDI) in Indonesia, 2010-2019 
In regional coverage for the Indonesian case, Yusuf et al. (2014) reported that Indonesia experienced divergence and convergence of regional development during the 1993-2013 observation period. The increase in inequality is significant (divergence), but the largest increase occurred in provinces or districts with low initial convergence rates. It also shows that Indonesia's regional development inequality has increased significantly, mostly seen in the period after the 1997-1998 crisis, or during the era of political reform and democratization. Before the crisis, inequality was relatively stable and moderate (if not slightly decreasing). The findings from the pre-crisis period are quite relevant to the observation period of this study. The inequality has been relatively stable, with a slight decline from 2010 onwards, though the political and economic conditions are almost the same.

In a global scope, the findings of this study are related to Noorbakhsh (2007), who used various measures to determine the dispersion of HDI between countries, including SD and CVw. The study found polarization in the human development index among developing countries with a slight reduction in world inequality. The results showed a convergence among middle and developing countries. However, considering the length of the period, the pace of convergence is very slow.

Figure 3 shows the description of regions with different HDI levels. It can be seen that the regions with HDI growth rates above average are in provinces with low and medium HDI levels. Contrastingly, regions with HDI growth rates below average are in provinces with high HDI levels. Therefore, convergence can be seen with a dominant pattern is in clusters I and IV. These findings are in line with the neoclassical theory hypothesis in cases of HDI between provinces in Indonesia.
The information in Figure 1 is linked to the analysis results in Figure 3, showing that provinces with relatively smaller DAU maintain growth rates above the average value, or relatively faster. This can be explained using the $\beta$-convergence analysis in the next section because it describes factors affecting the convergence process. Furthermore, there are still several provinces with lower HDI levels that experience relatively slower average growth rates, including Maluku, Bangka Belitung, Southeast Sulawesi, West Sumatra, Aceh, and North Sumatra. Therefore, there is a need for special attention to the growth rate to be pushed faster to optimize the convergence process. In this case, in the last year (2019), the provinces that had a lower HDI level should be prioritized, including Maluku, with a moderate HDI level of 69.45 (BPS, 2020). Other provinces with lower HDI levels, such as Papua, West Papua, NTB, Sulbar, and others, need to be maintained for their HDI to grow relatively faster consistently.

\subsection{Beta-Convergence Analysis ( $\beta$-Convergence)}

The estimation of human development models is conducted using dynamic panel data analysis methods, specifically the FD-GMM and Sys-GMM models. This is due to the dependent variable lag, human development index (HDI), the independent variable in the model specification. Static analysis of data panels with the Ordinary Least Square (OLS) and Fixed-Effects (FE) models is carried out to compare and determine one of the criteria for an appropriate dynamic panel data model approach. An unbiased estimator is determined using the continuum test. Furthermore, the dynamic panel data model with the correct predictor is tested using the Arellano-Bond test (LM-test), and a valid instrument assessed using the Sargan test.

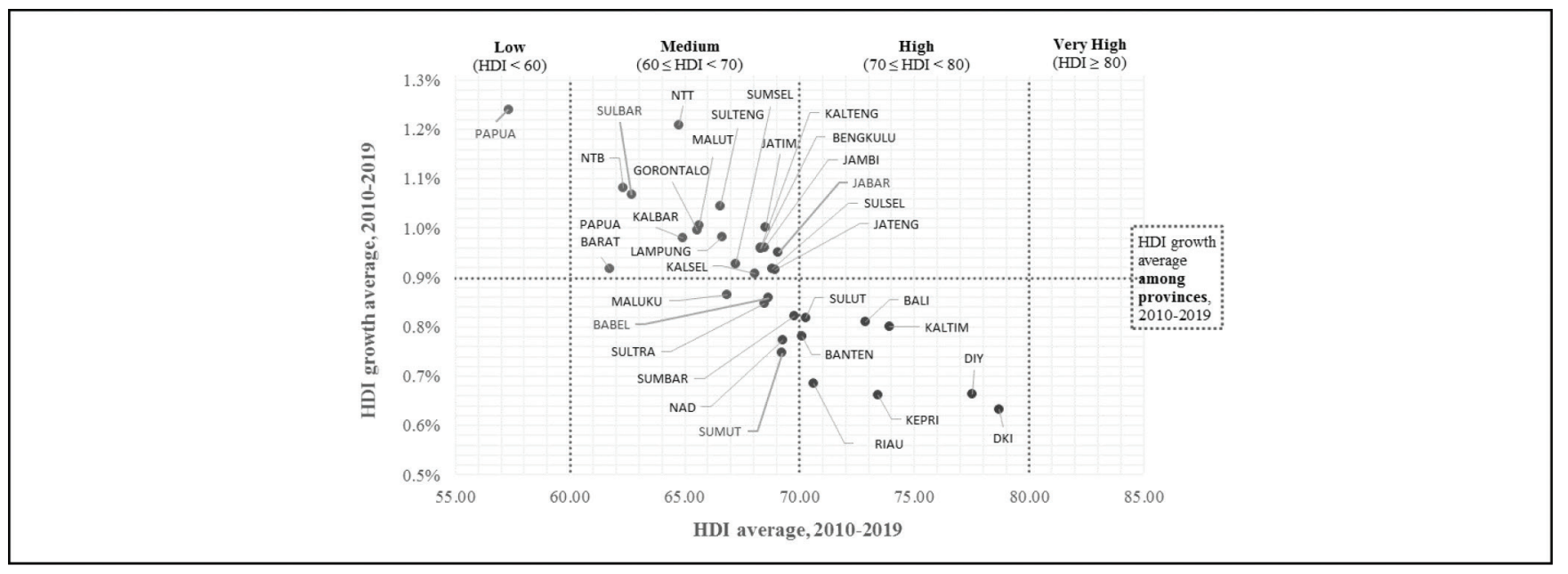

Figure 3: Clustering analysis of Human Development Index (HDI) among provinces in Indonesia 
Table 1: Estimation Results for Absolute of $\beta$-Convergence Models

\begin{tabular}{|c|c|c|c|c|}
\hline Parameters & OLS & FE & FD-GMM & Sys-GMM \\
\hline In_HDI $\mathrm{i}_{\mathrm{i},-1}$ & $\begin{array}{c}0.9821 \\
(0.000)^{*+* *}\end{array}$ & $\begin{array}{c}0.9931 \\
(0.000)^{*+*+*}\end{array}$ & $\begin{array}{c}0.9971 \\
(0.000)^{* * * *}\end{array}$ & $\begin{array}{c}0.9946 \\
(0.000)^{*+* *}\end{array}$ \\
\hline _cons & $\begin{array}{c}0.0842 \\
(0.000)^{* * * *}\end{array}$ & $\begin{array}{l}0.0376 \\
(0.115)\end{array}$ & $\begin{array}{c}0.0211 \\
(0.000)^{* * *}\end{array}$ & $\begin{array}{c}0.0317 \\
(0.000)^{* * * *}\end{array}$ \\
\hline Implied $\lambda$ & 1.80 & 0.68 & 0.29 & 0.54 \\
\hline Half-life & 38.46 & 101.55 & 239.10 & 128.08 \\
\hline Sargan test & - & - & $\begin{array}{c}32.9855 \\
(0.565)\end{array}$ & $\begin{array}{c}32.9552 \\
(0.866)\end{array}$ \\
\hline \multicolumn{5}{|c|}{ Arellano-Bond test } \\
\hline for $A R(1)$ & - & - & $\begin{array}{l}-4.1202 \\
(0.000)^{* * *}\end{array}$ & $\begin{array}{l}-4.1171 \\
(0.000)^{1+* *}\end{array}$ \\
\hline for $A R(2)$ & - & - & $\begin{array}{l}-0.3430 \\
(0.7316)\end{array}$ & $\begin{array}{c}-0.3459 \\
(0.729)\end{array}$ \\
\hline
\end{tabular}

Note: ${ }^{* *},{ }^{* *}$ and ${ }^{*}$ indicates significant at $1 \%, 5 \%$ and $10 \%$ level of significance based on t-statistics.

Dynamic panel data analysis is driven by the development of relationships between economic variables in relation to the dynamic adjustment analysis. This dynamic relationship is characterized by the presence of dependent variable lag as an independent variable, leading to endogeneity problems. In case the model is estimated by static panel data analysis, it produces biased and inconsistent estimators that can be overcome by the GMM model. The estimation results summary of the convergence model of human development in Indonesia is presented in Tables 2 and 3 for the absolute $\beta$-convergence and the conditional $\beta$-convergence model.

This section begins by analyzing the absolute $\beta$-convergence model with estimation results listed in Table 2 . The absolute $\beta$-convergence hypothesis is expected to be proven a priory. Otherwise, it can be challenging to accept that regional growth is only affected by the initial HDI level. When this is carried out, the model is prone to specification bias problems. Continuum testing on the model with FD-GMM shows that the coefficient estimator of the dependent variable lag (HDI lag) of 0.9971 is greater than the estimator with the FE model of 0.9931. It is also greater than the estimator with the OLS model of 0.9821 . This shows that the estimator with the FD-GMM model is biased. The Arellano-Bond test of the model with FDGMM stated that the AR (1) significance test with a test statistic of -4.1202 shows significant results. In contrast, the AR (2) significance test with a test statistic of -0.4359 shows insignificant results. This means the estimator with the FD-GMM model is consistent. The Sargan test results with a test statistic of 32.9855 showed insignificant results, stating that the estimator with the FD-GMM model used a valid instrument. Although the estimator with the FD-GMM model is consistent and uses valid instruments, the FD-GMM model is not appropriate. This is because the continuum test results indicate that the estimator is biased, and therefore, it is necessary to estimate using the SysGMM model.

The coefficient estimator of the dependent variable lag from the model with Sys-GMM experienced the same result as the previous FD-GMM model. Specifically, it was 0.9946 greater than the estimator model with FE of 0.9931 and OLS of 0.9821 . Since the continuum requirement is not fulfilled, the estimator is biased with this model. The Arellano-Bond test results also show AR (1) significance test results of -4.1171 , which is significant. However, the statistical test result of the AR (2) significance test is -0.3459 , which is insignificant. Therefore, the estimator with the Sys-GMM model is consistent. The Sargan test results with an insignificant statistical test of 32.9552 indicate that the Sys-GMM model's estimator is valid. The three test results show that the Sys-GMM model does not meet all the criteria for the right dynamic panel model. The finding breaks the characteristic homogeneity hypothesis in the absolute $\beta$-convergence analysis for human development in Indonesia. This means that human development's growth is not only influenced by the level of the initial human development index. There are differences in characteristics in technology, preferences, and institutions between regions in Indonesia. 
No conclusion can be drawn from the absolute $\beta$-convergence analysis in this study because the evidence is not robust, though it is not a serious problem. According to Salai-Martin (1996), $\beta$-convergence is a necessary condition for $\sigma$-convergence, but not sufficient for the occurrence of better increasingly income dispersion. The results of this study are different from Kharisma and Saleh (2012), which measured the convergence of development with the GDRP per capita with a strong indication of absolute $\beta$-convergence in Indonesia from 1984-2008. This may be reasonable because the observation period and the measured variables are different.

In a global context, the results of this study are in line with Noorbakhsh (2007), which examined the convergence concept extended to HDI, proving the weakness of absolute $\beta$-convergence in 1975-2002. The results are robust and verified by various conditional $\beta$-convergence models, supported by weak evidence for $\sigma$-convergence. The analysis supports the polarization in HDI among developing countries, though with a slight reduction in world inequality. The dynamics of the regional analysis show the movement of sub-Saharan Africa towards the low level of human development with Asia and Latin America making progress. High immobility at the start of a period followed by considerable up and down mobility at the end suggests a possible case of the 'twin peak' polarization. This condition is similar to the provinces in Indonesia, which have proven the hypothesis of neoclassical theory.

An analysis was conducted by estimating the conditional $\beta$-convergence model. The result showed that the dependent variable lag's estimator coefficient was 1.0272 greater than the estimator with the FE model of 0.9765 . It was also greater than the estimator with the OLS model of 0.9808 . This suggests that the estimator with the FD-GMM model is biased. The Arellano-Bond test on model with FDGMM stated that the AR (1) significance test with a test statistic of $-4,162$ shows significant results, while the AR (2) significance test with a test statistic of -0.8041 is insignificant. Therefore, the estimator with the FD-GMM model is consistent. The results of the Sargan test with a test statistic of 29.8993 (insignificant results) suggest that the estimator with the FD-GMM model uses a valid instrument. Although it is consistent and uses valid instruments, the model with the FD-GMM is not appropriate to use in the conditional $\beta$-convergence analysis. This is because the continuum test results indicate that the estimator is biased. Therefore, it is vital to estimate using the Sys-GMM model with estimation results in Table 3.

The lag coefficient estimator of the dependent variable from the Sys-GMM model is 0.877779 , greater than the estimator of the FE model but smaller than the estimator of the OLS model. Therefore, the continuum requirements are met, and the estimator is declared unbiased. The ArellanoBond test results show that the statistical significance test of AR (1) is $-2,0434$, which is significant. The statistical test result of the AR (2) significance test is 1.7691, which is not significant. This shows that the estimator with the SysGMM model is consistent. The Sargan test results with a test statistic of 25.8107, an insignificant state, and the estimator with the Sys-GMM approach is valid. The three test results show that the Sys-GMM model meets all the criteria for the right dynamic panel model, hence the analysis using the conditional $\beta$-convergence approach can be concluded.

The convergence model discussed provides information on several factors influencing the convergence of HDI in Indonesia. Intervention on these factors is necessary to accelerate the convergence process. The interventions should be focused on areas with lower HDI levels. This leads to faster human development and increases the rates of the convergence process. The HDI variable's lag coefficient, which is smaller than one, indicates that the convergence process occurs due to HDI inequality. This means the impact of transfer funds to regions in aggregate contributes to the convergence speed of HDI by $2.21 \%$ per year with a half-life of convergence or the time needed to cover the inequality of around 31 years.

The Sys-GMM estimation model in the analysis with the conditional $\beta$-convergence approach is the best aggregate model for explaining the impact of transfer funds to regions on the convergence of human development. In this study, the instruments of transfer funds to regions are explained partially for each variable consisting of revenue sharing fund (Dana Bagi Hasil, DBH), general allocation fund (Dana Alokasi Umum, DAU), special allocation fund (Dana Alokasi Khusus, DAK), and village fund (Dana Desa, DD).

The model gives DBH variable regression coefficient results in the aggregate model of -0.00011 . This implies that the DBH variable hurts human development. The $1 \%$ increase in $\mathrm{DBH}$ reduces the convergence of HDI by $-0.00011 \%$. Although the decrease in numbers is quite small (not significant), this negative impact still needs attention. This is a normal condition because the DBH allocated to the regions is based on a percentage figure, which depends on the amount of taxes and natural resources. Therefore, the taxes and natural resources from regions with a higher HDI level have relatively greater revenue than those with a lower HDI level.

The result of the DAU variable regression coefficient on the aggregate model is -0.00024 . This implies that the DAU variable hurts the convergence of HDI. The $1 \%$ increase in DAU reduces convergence by $-0.00024 \%$. Although the decrease in numbers is quite small (not significant), this negative impact still needs attention. Therefore, this condition is expected to turn into a positive. This condition is attributed to the HDI component, which is used as a formulation in assessing regional needs to determine the amount of DAU, has not become a top priority, even though this HDI is a goal of regional development. 
Table 2: Estimation Results for Conditional of $\beta$-Convergence Models

\begin{tabular}{|c|c|c|c|c|}
\hline Parameters & OLS & FE & FD-GMM & Sys-GMM \\
\hline In_HDI $\mathrm{i}_{\mathrm{i},-1}$ & $\begin{array}{c}0.9808 \\
(0.000)^{*+*+1}\end{array}$ & $\begin{array}{c}0.9765 \\
(0.000)^{*+*}\end{array}$ & $\begin{array}{c}1.0272 \\
(0.000)^{*+*+}\end{array}$ & $\begin{array}{c}0.9781 \\
(0.000)^{*+* *+}\end{array}$ \\
\hline In_RSF & $\begin{array}{c}-0.00011 \\
(0.378)\end{array}$ & $\begin{array}{c}0.000443 \\
(0.455)\end{array}$ & $\begin{array}{c}0.000088 \\
(0.762)\end{array}$ & $\begin{array}{c}-0.00011 \\
(0.599)\end{array}$ \\
\hline In_GAF & $\begin{array}{c}0.00047 \\
(0.284)\end{array}$ & $\begin{array}{c}-0.00120 \\
(0.463)\end{array}$ & $\begin{array}{l}-0.0029 \\
(0.000)^{+* t}\end{array}$ & $\begin{array}{c}-0.00024 \\
(0.511)\end{array}$ \\
\hline In_SAF & $\begin{array}{c}-0.00021 \\
(0.537)\end{array}$ & $\begin{array}{c}-0.00036 \\
(0.378)\end{array}$ & $\begin{array}{l}-0.00048 \\
(0.010)^{* * *}\end{array}$ & $\begin{array}{l}0.00056 \\
(0.000)^{*+*+}\end{array}$ \\
\hline dummy_VF & $\begin{array}{c}0.000906 \\
(0.086)^{*}\end{array}$ & $\begin{array}{c}0.001131 \\
(0.075)^{*}\end{array}$ & $\begin{array}{c}0.000639 \\
(0.067)^{*}\end{array}$ & $\begin{array}{c}0.00006 \\
(0.816)\end{array}$ \\
\hline _cons & $\begin{array}{c}0.0843 \\
(0.000)^{*+*}\end{array}$ & $\begin{array}{c}-0.06897 \\
(0.172)\end{array}$ & $\begin{array}{c}-0.0075 \\
(0.699)\end{array}$ & $\begin{array}{c}0.0953 \\
(0.000)^{*+* t}\end{array}$ \\
\hline Implied $\lambda$ & 1.93 & 2.37 & -2.69 & 2.21 \\
\hline Half-life & 35.82 & 29.21 & -25.78 & 31.42 \\
\hline Sargan test & - & - & $\begin{array}{c}29.8993 \\
(0.712)\end{array}$ & $\begin{array}{c}31.4151 \\
(0.904)\end{array}$ \\
\hline \multicolumn{5}{|c|}{ Arellano-Bond test } \\
\hline for $A R(1)$ & - & - & $\begin{array}{c}-4.162 \\
(0.000)^{*+*}\end{array}$ & $\begin{array}{l}--4.0731 \\
(0.000)^{*+* x}\end{array}$ \\
\hline for $A R(2)$ & - & - & $\begin{array}{c}-0.8041 \\
(0.421)\end{array}$ & $\begin{array}{c}-0.3778 \\
(0.705)\end{array}$ \\
\hline
\end{tabular}

Note: ${ }^{* * *},{ }^{* *}$ and ${ }^{*}$ indicates significant at $1 \%, 5 \%$ and $10 \%$ level of significance based on t-statistics.

The DAK variable has a regression coefficient of 0.00056 . This means that the DAK variable has a positive effect on the convergence of human development. The $1 \%$ increase in DAK will increase HDI significantly by $0.00056 \%$. This result is in line with the DAK objective to help fund special activities that are regional affairs and in line with national priorities, where the determination of national priorities starts from regions with lower levels of development. Therefore, these activities are expected to increase regional development with implications for increasing HDI.

The result of the village fund variable regression coefficient on the convergence model of human development in Indonesia is 0.00006 . This means that the village fund variable has a positive effect on the convergence of human development. An increase of $1 \%$ village fund increases the convergence of HDI by $0.00006 \%$, but the increase is still not maximal (not significant). Therefore, this condition is expected to be optimized. This is possible due to the implementation of the village fund program since 2015 for villages throughout Indonesia. The characteristics of HDI in villages are mostly lower than in cities due to the tendency for rural communities to have low access to education and health. Therefore, with this program, the village government pays additional costs to improve its development, which has implications for improving the quality of life in terms of education, health, and economy.

These results are in line with Wulandari et al. (2018) using path analysis, which stated that the original regional government revenue (Pendapatan Asli Daerah, PAD), general allocation fund, special allocation fund, and profit-sharing fund directly affect the HDI, though the convergence process is not analyzed. However, the results are slightly different from Mutiha (2018), which used different approaches and models. The study established that regional original income (PAD) has a significant positive impact on the HDI. By contrast, tax revenue sharing, general allocation fund, and the special allocation fund have a significant negative impact on the HDI. Although the study did not analyze the convergence process, it stated that at a certain level, the balancing fund is not used to finance direct expenditures, leading to a negative impact. Direct expenditure has a direct impact on the maintenance of public services, which also affects the improvement of the quality of human development. Therefore, it is vital to initiate analysis for further studies in balancing discussions from the government revenue and expenditure budgets. 
Some provinces with relatively smaller DAU and DBH maintain growth rates above the average, or relatively faster. This is because the performance of other balancing fund policies with a positive impact on the convergence process, such as the DAK and DD instruments, is still dominant. To improve it, the performance of all the balance fund instruments should be more synergized for a faster effect on the convergence process of human development in Indonesia. Furthermore, this fiscal policy instrument is relatively more effective in accelerating development convergence. According to Firdaus and Yusop (2009), regional convergence measured by per-capita income with investment and labor explanatory variables only has a convergence rate of $0.29 \%$ per year, which is very slow. For this reason, it can be more difficult for further intervention than fiscal policy instruments, which in principle can be directly intervened by the government.

The results of this study on village funds can explain the relationship between the influence of village funds, human development, and income inequality. Arham and Hatu (2020) found that the elasticity of income inequality is higher after the implementation of village fund transfer and also highlights the significance of human resources quality and agricultural sector in reducing poverty rate in rural areas. Furthermore, the study suggests that village fund transfer is insignificant in coping with the issue of income inequality, while education, which is a dimension of HDI, appears to be the determinant factor in tackling the issue of income inequality in the rural areas. Then Suhendra et al. (2020) found that human capital represented by the education index has a negative and significant effect on income inequality. The result implies that an increase in human capital results in a reduction in income inequality. So, it can be said that the current village funds have not been able to contribute to the decrease in income inequality, but based on this study it has been able to contribute to the reduction in human development inequality, it is estimated that it can reduce income inequality for the future in the long term.

\section{Conclusions}

Based on the analysis results and the problems and objectives of this study, several conclusions are drawn. First, static analysis with the $\sigma$-convergence approach using standard deviation and Williamson Index calculations shows a dispersion in the HDI inequality. This means that the convergence of human development prevails during the 2010-2019 period. The assertion is confirmed by the clustering analysis results, which shows that all provinces with higher HDI levels are relatively slower. Conversely, provinces with lower HDI levels are relatively faster, showing a catching-up process.
The dynamic analysis with the absolute $\beta$-convergence approach used in this study cannot reach a conclusion. This is because there are biases in the estimation results of the FD-GMM and Sys-GMM models. It is not sufficient to prove the convergence process due to unfulfilled criteria for the right dynamic panel model. However, this is not a serious problem because of its nature as a necessary condition. It is not sufficient for the progressive dispersion of human development and has been answered by the $\sigma$-convergence analysis in the previous section.

Dynamic analysis with the conditional $\beta$-convergence approach using the Sys-GMM model showed that a model built with explanatory variables for funds transfer to regions could lead to a convergence process in human development. The convergence rate is $2.21 \%$ per year, hence the time needed to cover the half-life of convergence is approximately 31 years. Based on the literature review, this condition is perceived to be quite slow. This is due to the special allocation fund (DAK) and the village fund (DD) with a positive contribution to the convergence process. It is also attributed to the special allocation fund (DAU) and the revenue sharing fund (DBH) with a negative sign, leading to a slowdown in the convergence process.

Both the static and dynamic analysis approaches are identical, and the convergence has been verified, though it is quite slow. This evidence opens up opportunities for reexamining the weighting component justification in determining the amount of transfer funds to the regions to accelerate the convergence process of human development. A possible solution to overcome this issue is giving more priority to the HDI weight. The intervention of these factors is essential to accelerate the convergence process. Furthermore, interventions should also be focused on areas with lower HDI levels to increase the growth rate for the development convergence process to be more quickly.

The provisional findings in this study may be robust, though there are still some limitations that open up opportunities for further research. For instance, observations over a longer period and with the most recent data may give more accurate results. The use of district or city analysis units may provide more comprehensive and in-depth analysis results, especially if it is related to fiscal decentralization policies managed up to the local governments at the district or city level. This study focused on regional budgets from budget revenues, hence the discussion on spending is needed to determine the government spending effectiveness in development. Modifying the explanatory variables composition to determine other factors contributing to the convergence process, especially in terms of government spending budgets, is necessary to determine its effectiveness. Additionally, spatial or regional issues should be applied, given the Indonesian territory characteristics as an archipelagic country. 


\section{References}

Abosedra, S., Arayssi, M., Ben Sita, B., \& Mutshinda, C. (2019). Exploring GDP growth volatility spillovers across countries. Economic Modelling, 89(C), 577-589. https://doi.org/10.1016/j. econmod.2019.11.015

Andreano, M. S., Laureti, L., \& Postiglione, P. (2013). Economic growth in MENA countries: Is there convergence of per-capita GDPs? Journal of Policy Modeling, 35(4), 669-683. https://doi. org/10.1016/j.jpolmod.2013.02.005

Apergis, N. (2015). Convergence in public expenditure across a sample of emerging countries: Evidence from club convergence. Emerging Markets Finance and Trade, 51(3), 448-462. https:// doi.org/10.1080/1540496X.2015.1025670

Arham, M. A., \& Hatu, R. (2020). Does Village Fund Transfer Address the Issue of Inequality and Poverty? A Lesson from Indonesia. Journal of Asian Finance, Economics and Business, 7(10), 433-442. https://doi.org/10.13106/jafeb.2020.vol7. no10.433

Bao, Y., \& Dhongde, S. (2009). Testing convergence in income distribution. Oxford Bulletin of Economics and Statistics, 71(2), 295-302. https://doi.org/10.1111/j.14680084.2008.00514.x

Barro, R. J., \& Sala-i-Martin, X. (1995). Economic Growth. NewYork, NY: McGraw-Hill Inc.

Barro, R. J., Sala-I-Martin, X., Blanchard, O. J., \& Hall, R. E. (1991). Convergence Across States and Regions. Brookings Papers on Economic Activity, 1991(1), 107. https://doi. org/10.2307/2534639

Barro, R. J., \& Sala-i-Martin, X. X. (1992). Convergence Xavier Sala-i-Martin. Journal of Political Economy, 100(2), 223-251. https://doi.org/10.1086/261816

Berk, I., Kasman, A., \& Kılınç, D. (2018). Towards a common renewable future: The System-GMM approach to assess the convergence in renewable energy consumption of EU countries. Energy Economics, 87(C). https://doi.org/10.1016/j. eneco.2018.02.013

Blundell, R., \& Bond, S. (1998). Initial conditions and moment restrictions in dynamic panel data models. Journal of Econometrics, 87, 115-143. https://doi.org/10.1016/S03044076(98)00009-8

Bouayad-Agha, S., \& Lionel, V. (2010). Estimation strategies for a spatial dynamic panel using gmm. a new approach to the convergence issue of european regions. Spatial Economic Analysis, 5(2), 205-227. https://doi. org/10.1080/17421771003730711

Castro, V., \& Martins, R. (2018). The Electoral Dynamics of Human Development. Journal of Development Studies, 54(1), 191-211. https://doi.org/10.1080/00220388.2017.1288221

Choi, H., \& Li, H. (2000). Economic development and growth convergence in china. Journal of International Trade and Economic Development, 9(1), 37-54. https://doi. org/10.1080/096381900362535
Chulanova, Z. K., Satybaldin, A. A., \& Koshanov, A. K. (2019). Methodology for assessing the state of human capital in the context of innovative development of the economy: A threelevel approach. Journal of Asian Finance, Economics and Business, 6(1), 321-328. https://doi.org/10.13106/jafeb.2019. vol6.no1.321

Cosci, S., \& Mirra, L. (2018). A spatial analysis of growth and convergence in Italian provinces: the role of road infrastructure. Regional Studies. https://doi.org/10.1080/00343404.2017.1334 117

Dash, B. B., \& Mukherjee, S. (2015). Political Competition and Human Development: Evidence from the Indian States. Journal of Development Studies, 51(1), 1-14. https://doi.org/10.1080/00 220388.2014.947280

Dobson, S., \& Ramlogan, C. (2002). Economic growth and convergence in Latin America. Journal of Development Studies, 38(6), 83-104. https://doi.org/10.1080/00220380412 331322591

Firdaus, M., \& Yusop, Z. (2009). Dynamic analysis of regional convergence in Indonesia. International Journal of Economics and Management, 3(1), 73-86.

Fufa, T., \& Kim, J. (2018). Financial development, economic growth and convergence clubs. Applied Economics. https://doi. org/10.1080/00036846.2018.1489521

Habibi, N., Huang, C., Miranda, D., Murillo, V., Ranis, G., Sarkar, M., \& Stewart, F. (2003). Decentralization and Human Development in Argentina. Journal of Human Development, 4(1), 73-101. https://doi.org/10.1080/1464988032000051496

Khan, U. S., Khan, M. A., Nawaz, S., \& Rahman, A. (2020). Fiscal Convergence and Total Factor Productivity : Firm-Level Evidence from Pakistan. Journal of Asian Finance, Economics and Business, 7(10), 555-569. https://doi.org/10.13106/ jafeb.2020.vol7.no10.555

Kharisma, B., \& Saleh, S. (2012). Convergence of Income Among Provinces in Indonesia: A Panel Data Approach. Journal of Indonesian Economy and Business, 28(2)(2), 167-187.

Li, K. W., Zhou, X., \& Pan, Z. (2016). Cross-country output convergence and growth: Evidence from varying coefficient nonparametric method. Economic Modelling, 55, 32-41. https:// doi.org/10.1016/j.econmod.2016.02.003

Liu, T. Y. (2019). Spatial structure convergence of China's transportation system. Research in Transportation Economics, 78(C) 100768. https://doi.org/10.1016/j.retrec.2019.100768

Magrini, S., Gerolimetto, M., \& Engin Duran, H. (2015). Regional Convergence and Aggregate Business Cycle in the United States. Regional Studies, 49(2), 251-272. https://doi.org/10.108 0/00343404.2013.766319

Männasoo, K., Hein, H., \& Ruubel, R. (2018). The contributions of human capital, R\&D spending and convergence to total factor productivity growth. Regional Studies, 52(12), 1598-1611. https://doi.org/10.1080/00343404.2018.1445848

Manuel Arellano and Stephen Bond. (1991). Some Tests of Specification for Panel Data: Monte Carlo Evidence and an 
Application to Employment Equations. Review of Economic Studies, 58(2), 277-297.

Marchante, A. J., \& Ortega, B. (2006). Quality of life and economic convergence across Spanish regions, 19802001. Regional Studies, 40(5), 471-483. https://doi. org $/ 10.1080 / 00343400600757460$

Mayer-Foulkes, D. (2012). Divergences and Convergences in Human Development. Indian Journal of Human Development, 6(2), 175-224. https://doi.org/10.1177/0973703020120202

Mutiha, A. H. (2018). The Effect of Regional Own-source Revenue, Tax Revenue-sharing Fund, General Allocation Fund and Special Allocation Fund to the Human Development Index (Based on the Study of Provincial Government in Indonesia). KnE Social Sciences, 3(11), 609. https://doi.org/10.18502/kss. v3i11.2792

Nayyar, D. (2012). Macroeconomics and human development. Journal of Human Development and Capabilities, 13(1), 7-30. https://doi.org/10.1080/19452829.2011.643121

Noorbakhsh, F. (2007). International Convergence or Higher Inequality in Human Development? Evidence for 19752002. Advancing Development, 9, 149-167. https://doi. org/10.1057/9780230801462_9

Ocampo, J. A., \& Vallejo, J. (2012). Economic growth, equity and human development in Latin America. Journal of Human Development and Capabilities, 13(1), 107-133. https://doi.org/ 10.1080/19452829.2011.637395

Raiser, M. (1998). Subsidising inequality: Economic reforms, fiscal transfers and convergence across Chinese provinces. Journal of Development Studies, 34(3), 1-26. https://doi. org/10.1080/00220389808422518

Sab, R., \& Smith, S. C. (2016). Human Capital Convergence: A Joint Estimation Approach. Palgrave Macmillan Journals on behalf of the International Monetary Fund Human Capital Convergence, 49(2), 200-211.

Sala-i-Martin, X. (1996). Regional cohesion: Evidence and theories of regional growth and convergence. European Economic Review, 40, 1325-1352.

Suhendra, I., Istikomah, N., Adi, R., Ginanjar, F., \& Anwar, C. J. (2020). Human Capital, Income Inequality and Economic
Variables: A Panel Data Estimation from a Region in Indonesia. Journal of Asian Finance, Economics and Business, 7(10), 571-579. https://doi.org/10.13106/jafeb.2020.vol7. no10.571

Verbeek, M. (2004). Modern Econometrics. Hoboken, NJ: John Wiley and Sons Inc.

Vidyattama, Y. (2013). Regional convergence and the role of the neighbourhood effect in decentralised Indonesia. Bulletin of Indonesian Economic Studies, 49(2), 193-211. https://doi.org/ $10.1080 / 00074918.2013 .809841$

Wang, X. (2020). Openness, growth convergence and China's development prospects. China Economic Journal, 13(1), 82108. https://doi.org/10.1080/17538963.2019.1591574

Williamson, J. G. (1965). Regional Inequality and the Process of National Development: A Description of the Patterns. Economic Development and Cultural Change, 13(4), 3-45.

Wulandari, E., Wahyudi, M., \& Rani, U. (2018). Effect of Original Local Government Revenues, General Allocation Funds, Special Allocation Funds, Share Funds, Other Legal Revenues, Budget Surplus/Deficit to Human Development Index Through Capital Expenditures: Case Study of Regencies/Municipalities in . Review of Integrative Business and Economics Research, 7(2), 125-137. https://doi.org/ ISSN: 2304-1013

Xueliang, Z. (2013). Regional Economic Convergence Mechanisms in the Yangtze River Delta. Social Sciences in China, 34(3), 140-158. https://doi.org/10.1080/02529203.2013.820562

Yaya, O. O. S., Furuoka, F., Pui, K. L., Jacob, R. I., \& Ezeoke, C. M. (2020). Investigating Asian regional income convergence using Fourier Unit Root test with Break. International Economics, 161, 120-129. https://doi.org/10.1016/j.inteco.2019.11.008

Yusuf, A. A., Sumner, A., \& Rum, I. A. (2014). Twenty Years of Expenditure Inequality in Indonesia, 1993-2013. Bulletin of Indonesian Economic Studies, 50(2), 243-254. https://doi.org/ $10.1080 / 00074918.2014 .939937$

Ze-Lei, X., Xin-ya, D., \& Fei, F. (2017). Convergence in China's high-tech industry development performance: a spatial panel model. Applied Economics, 49(4), 1-13. https://doi.org/10.108 $0 / 00036846.2017 .1305091$ 